\title{
Thismia clavarioides (Thismiaceae), a new species of Fairy Lantern from New South Wales
}

\author{
K.R. Thiele and P. Jordan
}

\begin{abstract}
Thiele, K.R. ${ }^{1}$ (Centre for Plant Biodiversity Research, CSIRO, GPO Box 1600, Canberra, ACT 2601, Australia) and Jordan, P. (1 Erith St, Bundanoon, NSW 2578, Australia) 2002. Thismia clavarioides (Thismiaceae), a new species of Fairy Lantern from New South Wales. Telopea 9(4): 765-771. A new species, Thismia clavarioides, is described, illustrated and compared with other Australian and similar extra-Australian species. A key to Australian species of Thismia is included, and the conservation status and affinities of the new species are discussed.
\end{abstract}

\section{Introduction}

Thismia Griffith is a small, poorly-known genus comprising c. 30 species of mycotrophic, leafless herbs. Centres of species and morphological diversity are in Malesia and tropical South America. Two species are temperate, T. rodwayi from south-eastern Australia and New Zealand, and T. americana in North America.

Thismia and number of related genera are variously placed in Burmanniaceae (as the tribe Thismieae Miers. e.g. Conn 1994 following Cronquist 1981) or segregated into Thismiaceae (e.g. Bedford \& Whalen 1993 following Dahlgren 1980). Jonker (1938), in a monograph of Burmanniaceae, treated all species known at that time, while Jonker (1948) treated all Malesian species for Flora Malesiana.

Jonker (1938) recognised seven genera in the Thismieae. Of these, the two African genera Oxygene Schltr. and Afrothismia Schltr. differ from Thismia in a number of significant morphological features, while the remaining genera (Triscyphus Taub. ex Warm., Glaziocharis Taub. ex Warm., Geomitra Becc. and Scaphiophora Schltr.) are separated on apparently trivial characters and probably would not be maintained as distinct in a modern classification. Geomitra was reduced to synonymy under Thismia by von Mueller (1890), and this status has been accepted recently by Stone (1980).

Two species of Thismia are currently described from Australia. Thismia yorkensis Cribb is known from two collections from rainforest on Cape York Peninsula in North Queensland (Cribb 1995). Thismia rodwayi F. Muell. has been recorded from widely scattered localities in Tasmania, Victoria, New South Wales, Queensland and the North Island of New Zealand (Curtis \& Morris 1994; Given 1981; Cribb 1986; Conn 1994; Bedford \& Whalen 1993). The New South Wales and Queensland records are based on a single specimen each, from Werrikimbe National Park (north-eastern NSW) and Kroombit Tops (Queensland). In addition, a fruit of an unidentified Thismia has been collected from the Lamington Plateau (South-East Queensland; Cribb 1986).

In June 2000 one of us (PJ) collected a fruiting specimen of Thismia from Coachwood (Ceratopetalum apetalum) rainforest near Bundanoon in the Southern Highlands of New South Wales. Flowering plants were subsequently found in the same area. Dissections of the flowering material and comparison with specimens of $T$. rodwayi and published

${ }^{1}$ Corresponding author 
descriptions and illustrations of other species shows that the Bundanoon plants comprise a new species, here described as T. clavarioides.

Thismia clavarioides K.Thiele sp. nov.

T. rodwayi similis sed floribus robustioribus, lobis interioribus perianthii mitriformibus unoquoque aristam dorsalem flexuosam erectam vel patentem robustam ferenti, et antheris caudis clavato-papillatis differt.

Holotype: Australia, New South Wales, Moreton National Park, Fairy Bower Falls, 3 Dec 2000, P. Jordan NSW 447624 (NSW).

Achlorophyllous herb with a creeping, fleshy, vermiform rhizome to $2 \mathrm{~mm}$ diameter. Leaves alternate, reduced to colourless scales to $10 \mathrm{~mm}$ long, the uppermost enclosing the base of the flower. Flowers scarcely to fully emergent above ground level, solitary on sinuous scapes to $75 \mathrm{~mm}$ long, rather fleshy, colourless or the distal portions where emergent grading to dull pale orange; perianth to $65 \mathrm{~mm}$ long (including the dorsal processes on the perianth lobes); tube (6-)10-13(-16) $\mathrm{mm}$ long, (5-)8-9(-12) $\mathrm{mm}$ wide, narrowed just above the ovary and below the perianth lobes, inflated in the middle and broadest in the upper third, coarsely 6-ribbed, the ribs irregularly rugose; outer perianth lobes (3-)9-11(-14) mm long, erect or spreading and slightly recurved, each comprising an attenuate, cylindrical bristle enclosed for the lower two thirds by a prominent, recurved wing, the apex of the wing free and forming a small limb adaxially; inner perianth lobes thick, cuneate, broadly fused apically by their cuticles (inseparable without tearing) to form a mitreform hood above the mouth of the perianth tube with three arch-shaped openings, each with a prominent dorsal, fleshy, erect or spreading, flexuose, tentacle-like awn (8-)20-25(-43) $\mathrm{mm}$ long; stamens included, colourless; anthers extrorse, laterally connate into a ring hanging from a short, lobed corona at the mouth of the perianth tube, each with two shallow loculi, a fine, terminal bristle terminating in a club-shaped group of papillae, and a distal, threelobed, skirt-like appendage sparsely margined with short, stiff hairs; nectaries (?) present on the anther appendages; style short, with three short, broad, shallowly bilobed, fan-like lobes; ovary inferior, flat-roofed, unilocular; placentas 3 , free, fusiform, each joined at the apex and base of the loculus. Fruit c. $6 \mathrm{~mm}$ diameter, fleshy, whitish, ovoid, surmounted by a persistent thickened ring of perianth tissue and a persistent style-knob. Seeds golden-brown, globoid-ellipsoid, c. $0.3 \times 0.25 \mathrm{~mm}$, shallowly elongate-reticulate. (Fig. 1).

Derivation of epithet: derived from Clavaria (a genus of coral fungus) and the ending -oides (similar to), in allusion to the resemblance of the fleshy awns of the half-buried flowers to the coloured thalli of some coral fungi.

\section{Key to the Australian species of Thismia}

1 Mitre without processes; roots coralloid T. yorkensis

1a Mitre with three apical or subapical processes; roots vermiform 2

2 Mitre-processes terminal, spreading or appressed to mitre, $<5 \mathrm{~mm}$ long; terminal bristle of anther simple T. rodwayi

2a Mitre-processes dorsal, erect or spreading, usually $>20 \mathrm{~mm}$ long; terminal bristle of anther papillate-clavate T. clavarioides 


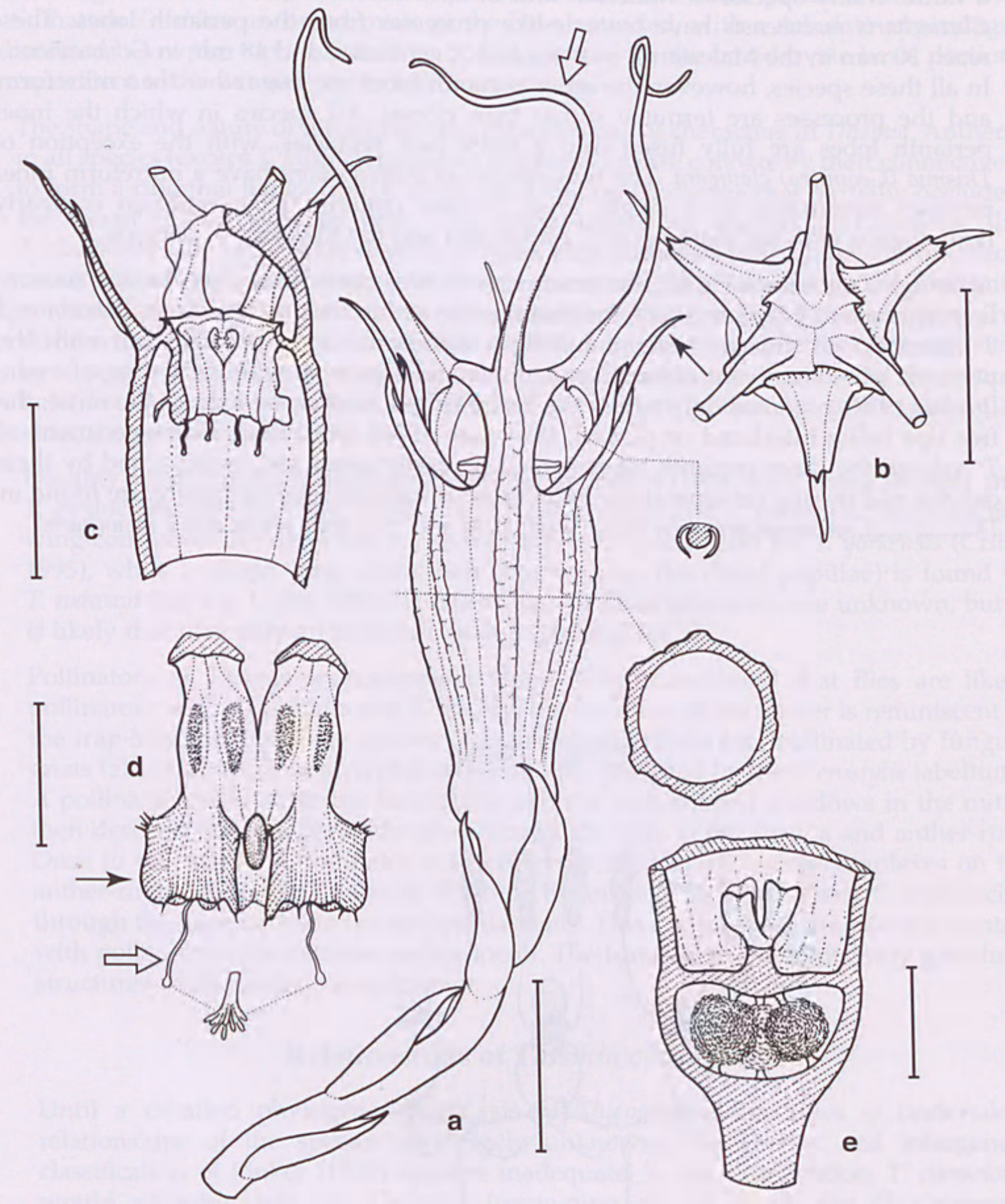

Fig. 1. Thismia clavarioides. a, flower, lateral view with $\uparrow$ tentacle-like awn, and $\uparrow$ outer perianth lobe with cylindrical bristle enclosed by recurved wing. $\mathbf{b}$, flower from above (tentacle-like awns truncated). c, perianth apex in section showing stamen ring. $d$, two detached stamens, extrorse face with $\uparrow$ fine terminal bristle terminating in club-shaped group of papillae, and $\uparrow$ distal skirt-like appendage. e, ovary. Scale bars: $a-c=10 \mathrm{~mm} ; d=2 \mathrm{~mm} ; \mathrm{e}=3 \mathrm{~mm}$. 


\section{Discussion}

Thismia clavarioides is particularly distinctive for the thick, attenuate, tentacle-like awns arising dorsally from the inner perianth lobes, which are fused by their cuticles to form a mitre. Many species of Malesian and South American Thismia and the Brazilian Glaziocharis macahensis have tentacle-like processes from the perianth lobes. These reach $30 \mathrm{~mm}$ in the Malesian T. javanica and T. arachnites, and $48 \mathrm{~mm}$ in G. macahensis. In all these species, however, the inner perianth lobes are free rather than mitreform, and the processes are terminal rather than dorsal. All species in which the inner perianth lobes are fully fused into a mitre lack tentacles, with the exception of Thismia (Geomitra) clavigera. The two species of Scaphiophora have a mitreform inner perianth terminated by a single, erect, 3 -lobed column. This condition is clearly homologous with the tentacles of $T$. clavarioides and the Malesian T. clavigera.

Although a mitreform versus free inner perianth was considered a generic and sectionlevel character by Jonker (1938), the states grade within the genus. Thismia rodwayi and T. americana are intermediate in having a mitreform inner perianth but with the perianth lobes connivent rather than connate and separable without tearing of tissue (Jonker 1938), or 'fused only where the fleshy ridges meet at the apex of the mitre, the free tips being interlaced or plaited' (Coleman 1936). In at least some specimens of T. rodwayi the inner perianth lobes cannot be easily separated, being glued by their cuticles and tearing on separation. Fully fused mitreform inner perianths are found in Thismia section Sarcosiphon, in Thismia clavigera and in Scaphiophora and Glaziocharis.

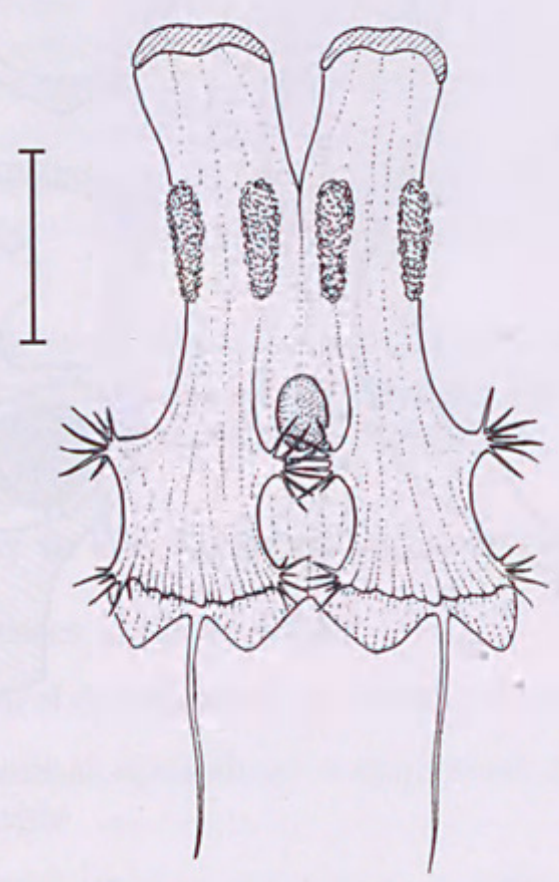

Fig. 2. Anthers of $T$. rodwayi, extrorse face. Scale bar $=2 \mathrm{~mm}$. 
The outer perianth lobes of Thismia clavarioides are distinctive. In most species of Thismiaceae these are simple and triangular or filiform; in T. clavarioides by contrast they are narrowly but distinctly winged, with the wings reflexed and partially wrapped around the central, cylindrical rib portion. The apex of the wing is free adaxially, forming a small limb. Jonker (1948, p. 23) describes the outer perianth lobes of the Sumatran T. labiata as 'broad-ovate at the base, rounded, with a subulate appendage inserted below the top'; this may be homologous, with the broad-ovate basal portion equivalent to the winged portion of $T$. clavarioides.

The shape and nature of the anther-ring provides useful characters in Thismia. Anthers in all species (except T. hyalina) have free filaments but are connate by their connectives to form a ring that hangs from a short, often thickened corona that partially occludes the throat of the perianth tube. The anther-loculi are shallow and extrorse. In T. clavarioides the anthers are distally winged, each anther bearing on the antrorse face two longitudinal lateral wings joined by a transverse, skirt-like wing. The filaments are broadly inserted on the corona with narrowly triangular gaps between them. The distal wings bear a few short, stiff hairs on their angles, and each anther is terminated by a single long, slightly flexuose, distally papillose-clavate bristle. On the suture between each pair of anthers distally is a prominent, glistening, ovoid glandular structure, possibly a nectary.

Possibly similar anther glands are described by Jonker (1948) for Thismia javanica and T. gardneriana and by Cribb $(1986,1995)$ for T. rodwayi and T. yorkensis. Distal anther wing-complexes are described for many Malesian species and for T. yorkensis (Cribb 1995), while a single, long, distal hair (but without the distal papillae) is found in T. rodwayi (see e.g. Conn 1994). The functions of these structures are unknown, but it is likely that they play an important role in pollination.

Pollinators of Thismia are unknown. Stone (1980) considered that flies are likely pollinators. In $T$. clavarioides and $T$. rodwayi the structure of the flower is reminiscent of the trap-structures of some species of Pterostylis (Orchidaceae) pollinated by fungusgnats (although without an irritable trapdoor as provided by the Pterostylis labellum). A pollinator could enter the flower through the arch-shaped windows in the mitre, then descend into the perianth-tube through the hole in the corona and anther-ring. Once in the tube, the pollinator may be constrained by the wing-complexes on the anther-ring to leave the flower by climbing the inside wall of the perianth and forcing through the gaps between the anther filaments. This would bring the insect in contact with pollen from the extrorse anther-loculi. The function of the apparently glandular structures on the anthers is unknown.

\section{Relationships of Thismia clavarioides}

Until a detailed phylogenetic analysis of Thismia and its allies is undertaken, relationships of the species are largely unknown. The generic and infrageneric classification of Jonker (1938) appears inadequate. In his classification, T. clavarioides would probably fall into Geomitra (containing the single species G. clavigera = Thismia clavigera). Superficially, flowers of $T$. clavarioides appear similar to those of T. clavigera, but that species has minute, triangular outer perianth lobes, and inner perianth lobes with erect tentacles arising from a central point on the mitre rather than dorsally from each lobe. The anthers of $T$. clavigera lack the distal wings and central hair of $T$. clavarioides. Vegetatively, $T$. clavarioides and $T$. clavigera are very different, the latter having coralliform, fan-shaped roots, and many leaves and flowers on each stem.

In vegetative and internal floral morphology $T$. clavarioides is very similar to T. rodwayi, and is probably closely related to it. In particular, the anther appendages of the two species are almost identical (Figs 1d, 2). A number of specimens of $T$. rodwayi examined 
at MEL differed from T. clavarioides in having larger, deeply coloured, slightly more robust anthers but with thinner and more erose distal wings, more prominent groups of stiff hairs on the angles of the wings, and with the terminal hairs lacking papilloseclavate tips. The paucity of good material, however, makes it difficult to assess the range of variation in these features.

Mueller (1890), in reporting the discovery of T. rodwayi, expressed astonishment at finding a Thismia in temperate Australia. Jonker (1938) placed T. rodwayi with the Northern Hemisphere temperate T. americana in Section Rodwaya Schltr. Indeed, Jonker (loc. cit. p. 12) considered that the two species may be identical. Many authors have since commented on these surprising systematic and biogeographic anomalies (e.g. Coleman 1941; Campbell 1968; McLennan 1958; Scarlett \& Parsons 1993). However, T. americana, as best can be determined from the descriptions and illustrations of the single known specimen, differs from both $T$. rodwayi and $T$. clavarioides in having no appendages on the anther connectives, a geniculate perianth tube and in having all perianth parts of approximately equal size. It is almost certainly not closely related.

\section{Distribution, habitat and conservation status}

Thismia clavarioides is currently known from only a small area in Morton National Park near Bundanoon. Two clusters of plants c. $50 \mathrm{~m}$ apart have been located, one covering an area approximately $2.5 \mathrm{~m} \times 2.5 \mathrm{~m}$, the other smaller. Since the rhizomes are thin and difficult to trace without disturbing the plant, it is impossible to determine whether each of these patches comprises a single clone. In the larger patch c. 15 flowers were observed in Spring 2000, while only 3 flowers were observed in the smaller patch. Flowers varied in their degree of emergence from the leaf litter, but most had the perianth tube below litter level with only the mitre and tentacles showing,

Both patches are in Coachwood (Ceratopetalum gummiferum) rainforest in humus-rich, colluvial soil and leaf litter over Hawkesbury Sandstone, on a south-facing slope near a stream. Associated species include Acmena smithii, Backhousia myrtifolia, Eucryphia moorei, Tristaniopsis laurina and various ferns. Since this vegetation is relatively extensive along gully bottoms and on sheltered aspects in the area, it may be expected that there are other populations yet undiscovered. The species may be locally common, but its cryptic nature makes this difficult to determine without further surveys.

Given the cryptic habit of $T$. clavarioides and uncertainty over its status and likely distribution, we consider that it should be given a conservation rating of 2 Kcit (Briggs \& Leigh 1996). While its low known population number would warrant a status of Critically Endangered under the IUCN Red List categories (IUCN 1994), this is probably premature until further surveys of suitable habitat are conducted.

\section{Acknowledgments}

We thank Neville Walsh and Judy West for comments on the manuscript and Ian Brooker for preparing the Latin diagnosis.

\section{References}

Bedford, D.J. \& Whalen, A.J. (1993) Thismiaceae. In G.J.Harden (ed.) Flora of New South Wales, vol. 4. (New South Wales University Press: Sydney).

Briggs, J.D. \& Leigh, J.H. (1996) Rare or Threatened Australian Plants. (CSIRO Publishing: Melbourne).

Campbell, E.O. (1968) An investigation of Thismia rodwayii F. Muell. and its associated fungus. Trans. R. Soc. N. Z., Bot. 3(14): 209-219. 
Coleman, D.G. (1936) Sarcosiphon rodwayi in Australia. Vict. Nat. 52: 163-6.

Coleman, D.G. (1941) Further notes on 'Fairy Lanterns'. Vict. Nat. 57: 167-8.

Conn. B.J. (1994) Burmanniaceae. In N.G. Walsh \& T.J. Entwisle (eds) Flora of Victoria, vol. 2 (Inkata Press: Melbourne).

Cribb, A.B. (1986) An extension of the range of Thismia rodwayi to Queensland. Queensl. Nat. 27: $18-21$.

Cribb, A.B. (1995) The saprophytic flowering plant, Thismia yorkensis sp. nov., from Australia. Queensl. Nat. 33: 51-54.

Cronquist, A. (1981) An integrated system of classification of flowering plants. (Columbia University Press: New York).

Curtis, W.M. \& Morris, D.I. (1994) The Student's Flora of Tasmania 4B: Angiospermae: Alismataceae to Burmanniaceae. (St. David's Park Publishing: Hobart).

DahIgren, R.M. (1980) A revised system of classification of the angiosperms. Bot. J. Linn. Soc. 80: 91-124.

Given, D.R. (1981) Rare and Endangered Plants of New Zealand. (Reed: Wellington).

Jonker, F.P. (1938) A monograph of the Burmanniaceae. Meded. Bot. Mus. Herb. Rijks Univ. Utrecht 51: $1-279$.

Jonker, F.P. (1948) Burmanniaceae. In C.G.G.J. van Steenis (ed.) Flora Malesiana I, 4: 12-26 (Noordhoff: Leiden).

McLennan, E.I. (1958) Thismia rodwayi F. Muell. and its endophyte. Aust. J. Bot. 6: 25-37.

Mueller, F. von (1890) Notes on a new Tasmanian plant of the Order Burmanniaceae. Pap. Roy. Soc., Tasmania 1890: 232-5.

Scarlett, N.H. \& Parsons, R.F. (1993) Rare or threatened plants in Victoria. In D.B. Foreman \& N.G. Walsh (eds) Flora of Victoria, vol. 1 (Inkata Press: Melbourne).

Stone, B.C. (1980) Rediscovery of Thismia clavigera (Becc.) F.v.M. (Burmanniacae). Blumea 26: 419-425. 


\section{$2 \mathrm{BHL}$ Biodiversity Heritage Library}

Thiele, Kevin and Jordan, P. 2002. "Thismia clavarioides (Thismiaceae), a new species of Fairy Lantern from New South Wales." Telopea: Journal of plant systematics 9(4), 765-771. https://doi.org/10.7751/telopea20024015.

View This Item Online: https://www.biodiversitylibrary.org/item/266176

DOI: https://doi.org/10.7751/telopea20024015

Permalink: https://www.biodiversitylibrary.org/partpdf/283170

\section{Holding Institution}

The Royal Botanic Gardens and Domain Trust, New South Wales, Australia

\section{Sponsored by}

Atlas of Living Australia

\section{Copyright \& Reuse}

Copyright Status: In copyright. Digitized with the permission of the rights holder.

Rights Holder: The Royal Botanic Gardens and Domain Trust, New South Wales, Australia License: http://creativecommons.org/licenses/by-nc-sa/4.0/

Rights: http://biodiversitylibrary.org/permissions

This document was created from content at the Biodiversity Heritage Library, the world's largest open access digital library for biodiversity literature and archives. Visit BHL at https://www.biodiversitylibrary.org. 